\title{
STUDY OF SPECIFICITIES OF ARM WRESTLERS' PSYCHOLOGICAL STATUS IN COMPETITION PERIOD
}

Podrigalo L. V., Galashko M. N., Galashko N. I.

Kharkov State Academy of Physical Culture

\begin{abstract}
Purpose: researching and analysis of psychological status dynamic of different qualification arm-wrestlers in competitions' condition. Material: in the research 21 students-sportsmen of 17-24 years' age participated. Results: before the beginning of competition experienced sportsmen are characterized by higher workability in comparison with beginners - $(56.61 \pm 8.31) \%$ against $(23.23 \pm 11.93) \%$. After competitions among experienced sportsmen $57.14 \%$ had reduced anxiety; $71.43 \%$ - reduced activity and self-feeling; 50\% - had worse mood. After competitions among sportsmen-beginners $73.73 \%$ demonstrated reduction of workability; $54.54 \%$ had weakened activity, mood and selffeeling. We established significant prevalence of statistically confident correlations among experienced sportsmen: $65.15 \%$ against $46.97 \%$. Contribution of psychological components in system of sportsmen-beginners is significantly lower than of experienced sportsmen. Conclusions: we determined certain changes of psychological status of armwrestlers of different qualification under influence of competitions. For experienced sportsmen we confirmed more optimal status and favorable dynamic, illustrating high reliability of functioning.
\end{abstract}

Key words: arm-wrestling, psychology, inter-connections, students, competitions.

\section{Introduction}

Sport functioning is characterized by rather intensive impact on psychic, which is conditioned by its stress-genic influence. Factors of sport stress include: competitive character of sport struggle, oriented on record or victory; maximal tension of all physical and psychic forces of a sportsman; systemic sport training, which contributes serious corrections to mode of life; domestic conditions of sportsmen [2].

Success and rising of sportsmanship in every kind of sports are determined by complex, which includes (together with physical and functional components) psychic features [2, 15, 17, 20, 21, 25, 27, 28, 34]. With levels of physical fitness being nearly equal, exactly psychological fitness becomes a decisive factor for achievement of high results and ability to control it is a criterion of successfulness $[4,10]$. We have determined certain distinctions in psychological status of sportsmen of different qualification; for example more experienced sportsmen are more aggressive than representatives of mass sport or people, who do not practice sports at all [12, 22, 32]. Development of sportsmen's skills of self-regulation is of great importance for maximal realization of their potentials [10, 13, 14, 23, 30, 31, 33]. Among factors, which condition formation of these mechanisms, central place is taken by self-assessment. It determines orientation and level of subject's activity, formation of his (her) personality [11, 24, 26, 29]. In martial arts competition result to large extent depends on sportsman's psychic status. Psychological training of a sportsman shall result in stability of combat fitness, i.e. in maximal mobilization for achievement of result [4].

For achievement of elite level in arm wrestling (AW) importance of sportsmen's morphological-functional state was confirmed [6, 7]. Considering specificities of this kind of sports (as martial art) psychological status acquires great significance; it's dynamic in process of training and competition loads. However, till present time there have been absent works, devoted to studying of this scientific task. It predetermined the urgency of our researches.

\section{Purpose, tasks of the work, material and methods}

The purpose of the work was research and analysis of psychological status dynamic of AW sportsmen of different qualification under influence of competition loads.

The participants of the research (21 AW sportsmen) were divided into two groups, depending on their sportsmanship: $1^{\text {st }}$ group -7 persons (mean age $23.71 \pm 1.44$ years), qualification - from $1^{\text {st }}$ grade to master of sports; $2^{\text {nd }}$ group - 11 participants (mean age $18.55 \pm 0.68$ years, 3 - sportsmen of mass grades.

The structure of the research implied studying and analysis of sportsmen's psychological status before and after competitions. As a test instrument we used complex test TPAHC, worked out by specialists of Kharkov national medical university. Choice of test was conditioned by researches, which proved its adequacy in studying of influence of intensive

(c) Podrigalo L. V., Galashko M. N., Galashko N. I., 2015 http://dx.doi.org/10.15561/20755279.2015.0306 
visual-information loads on schoolchildren's functional state and by available information about significant fluctuations of psychological status ( as components of forming pre-nosological state) $[3,5]$.

The test permits to determine dynamic of such indicators as anxiety, workability, activity, mood and self-feeling. The tool for self assessment is a blank form, consisting of 40 lines. Information is presented as two adjectives, opposite by meaning as well as in the form of digits, which mean degree of expressiveness of every sign: 3 - strong expressiveness; 2 - middle; 1 - weak expressiveness of sign. Methodic of data processing is analogous to test SAM (Self-feeling, Activity, Mood) [9].

The research was conducted before and after competitions. Interval between tests was in group $1^{\text {st }}-(3.47 \pm 0.55)$ hours, in group $2^{\text {nd }}-(3.57 \pm 0.38)$ hours. It permits to speak about closeness of time intervals, to presuppose type-likeness of adaptation responses.

Statistical analysis of the received data was carried out with the help of license packages of electronic table Excel with determination of parametric and non-parametric criteria [1].

\section{Results of the research}

Results of the research (see table 1) permit to say about closeness of psychological statuses of the participants of the researches and witness about similar orientation of their changes in dynamic of competitions and depending on level of sportsmanship.

Table 1

Psychological status of arm wrestlers in dynamic of competitions

\begin{tabular}{|l|c|c|}
\hline \multicolumn{1}{|c|}{ Indicators (\%) } & $1^{\text {st }}$ group & $2^{\text {nd }}$ group \\
\hline Initial anxiety & $47.09 \pm 11.62^{3}$ & $21.55 \pm 9.31$ \\
\hline Final anxiety & $52.37 \pm 4.88^{1}$ & $18.18 \pm 9.93$ \\
\hline Initial workability & $56.61 \pm 8.31^{1}$ & $23.23 \pm 11.93$ \\
\hline Final workability & $31.74 \pm 7.09^{2}$ & $21.55 \pm 9.64$ \\
\hline Initial activity & $38.08 \pm 13.38$ & $21.97 \pm 10.16$ \\
\hline Final activity & $30.36 \pm 10.27$ & $17.42 \pm 8.22$ \\
\hline Initial state of mood & $55.41 \pm 9.20$ & $33.05 \pm 9.67$ \\
\hline Final state of mood & $46.75 \pm 15.99$ & $24.52 \pm 12.33$ \\
\hline Initial self feeling & $62.71 \pm 11.89$ & $41.53 \pm 11.43$ \\
\hline Final self feeling & $44.28 \pm 8.28$ & $36.97 \pm 9.23$ \\
\hline
\end{tabular}

Notes: 1 - distinctions between groups are confident $(\mathrm{p}<0.05), 2-$ distinctions in dynamic are confident $(\mathrm{p}<0.05), 3-$ tendency to confidence of distinctions between groups $(\mathrm{p}<0.1)$.

Before competitions experienced sportsmen are characterized by higher workability, comparing with the beginners. It, in our opinion, shall be assessed as evidence of better readiness for competitions. At the same time anxiety in $1^{\text {st }}$ group was confidently higher than in the $2^{\text {nd }}$. This fact, considering situational character of this quality shall be assessed as positive factor, illustrating response to results of performances.

Besides, in group of experienced sportsmen we found confident reduction of workability in dynamic of competitions with the help of parametric criterion (Student's criterion) and non-parametric indicators (the sign criterion). In our opinion it can be assessed as evidence of forming in the process of competitions fatigue and as indirect illustration 
of full dedication of sportsmen to this functioning. The determined tendency to increasing of anxiety level before competitions in the given context can be explained by experienced sportsmen's stress of expectation.

With regarding the question from position of reliability of systems' functioning studying of situational anxiety is more interesting. It is conditioned by the fact that sportsman can "adjust" to competition process, "to subdue" this anxiety at the account of experience and certain adaptation to stresses, appearing in connection with competition functioning. Thus, he can increase his psychological stability. It is known that the oftener sportsman "oversteps" his fear the more adequate his response in extreme situation is; the higher hid psychological stability (reliability) is [4].

Using conception "pre-nosological diagnostic" in context of sportsmen's functional fitness, it is necessary to regard initial state as reflection of functioning level. Final state shall be regarded as illustration of functional reserves [5]. In our case stability of output functional characteristics of system is the basis of its high reliability, ensuring effective achievement of goals of functioning.

Analysis of individual features also permitted to find out certain distinctions between groups. Before competitions experienced sportsmen did not demonstrate negative indicators of anxiety, workability, mood and self-feeling. Only one participant $\left(14.29 \%\right.$ ) had negative value of activity. At the same time in $2^{\text {nd }}$ group negative indicators of anxiety were intrinsic to 4 participants (36.36\%), workability - to $3(27.27 \%)$, activity, mood and self feeling - to 2 sportsmen $(18.18 \%)$. After competitions in $1^{\text {st }}$ group there were no negative indicators of anxiety, workability and self feeling. 1 participant (14.29\%) was characterized by negative activity and $2(28.58 \%)$ - by negative state of mood. At the same time, after competitions among sportsmen-beginners 3 persons $(27.27 \%)$ had negative indicators of anxiety and mood, 2 $(18.18 \%)$ - workability and self-feeling and 1 (9.09\%) - activity. The received data permit to speak about worse psychological status of sportsmen-beginners and its more expressed aggravation under influence of competition loads, comparing with experienced colleagues.

Insufficient scope of samples conditioned increase of error of mean group values that does not permit to speak about confident shifts; however it gives basis for determination of tendencies of changes. For example we found out that after competitions in $1^{\text {st }}$ group $57.14 \%$ of participants were characterized by reduction of anxiety, $71.43 \%$ had weakened activity and self-feeling and $50 \%$ - state of mood. These shifts confirm made earlier assumptions about formation of fatigue and tiredness against the background of optimizing of psycho-emotional status.

We received interesting data when analyzing results of two masters of sports, who participated in our researches. They were characterized by increasing of activity and state of mood with minima negative changes in self feeling and workability. One of them demonstrated reduction of anxiety, the second - its minimal growth. Thus, the presented data permit to assume that experienced sportsmen are characterized by optimizing of psychological status and high stressresistance. Such level of stability ensures increase of reliability of organism's functioning in extreme conditions.

In $2^{\text {nd }}$ group reduction of anxiety and workability was registered in $73.73 \%$ of participants, while $54.54 \%$ had reduction of activity, state of mood and self-feeling. I.e. sportsmen-beginners had more expressed negative changes of psychological status. They reflect not only already formed fatigue but also witness about lower level of psychological readiness for competition loads.

Our researches confirmed validity of correlation matrixes method for analysis of AW sportsmen's condition [6] that exactly conditioned its usage in the given case. Main indicators of correlation structures are given in table 2.

Table 2

Indicators of correlation matrixes of arm wrestlers' psychological status

\begin{tabular}{|c|c|c|c|c|}
\hline Group & $\begin{array}{l}\text { Specific weight of } \\
\text { significant } \\
\text { correlations }(\%)\end{array}$ & $\begin{array}{l}\text { Specific weight of } \\
\text { confident } \\
\text { correlations }(\%)\end{array}$ & $\begin{array}{c}\text { Indicator of } \\
\text { labilization/synchronization } \\
(\%)\end{array}$ & $\begin{array}{c}\text { Mean coefficient of } \\
\text { correlation }\end{array}$ \\
\hline 1 & 65.15 & 18.18 & 22.22 & 0.56 \\
\hline 2 & 46.97 & 30.30 & 16.56 & 0.56 \\
\hline
\end{tabular}


Substantial prevalence of significant connections among correlations of $1^{\text {st }}$ group sportsmen was established that shall be assessed as evidence of their more stable status, i.e. better fitness for competitions. In respect to specific weight of confident connections situation is opposite that conditioned by different quantity of groups' members. For example in $1^{\text {st }}$ group minimal value of confident correlation $(\mathrm{p}<0.05)$ was 0.67 . Then in $2^{\text {nd }}$ group it was 0.55 . It resulted in substantial differences between specific weights of the mentioned correlations. So it seems to be possible to compare correlation matrixes just by quantity of significant connections.

Increase of labilization/synchronization indicator in $1^{\text {st }}$ group confirms mentioned earlier assumption about better functional state of experienced sportsmen. Their organisms are characterized by more balanced, more synchronized state. Lability of functions is less, comparing with sportsmen-beginners. It permits to predict high level of successfulness. The value of mean correlation coefficient in both cases was the same and related to interval of mean correlations. It permits to consider that in both cases systems were sufficiently stable, without rough violations, facilitating imbalance.

Thus, comparative analysis of correlation structures of psychological status's indicators of different qualification AW sportsmen permits to conclude that the studied psychological status's components are rather close. Absence of rough violations is confirmed by similar mean values of system's correlation, which is in interval of correlations of moderate strength in both groups. At the same time experienced sportsmen are characterized less label state. They have significantly less imbalance of regulation. Stability of system in this case is ensured by sufficient quantity of significant connections. They permit to minimize reduction of system's reliability, conditioned by influence of competition stress.

In order to study contribution of every of analyzed factors into system we determined indicators of system's formation (SI) (see fig. 1).

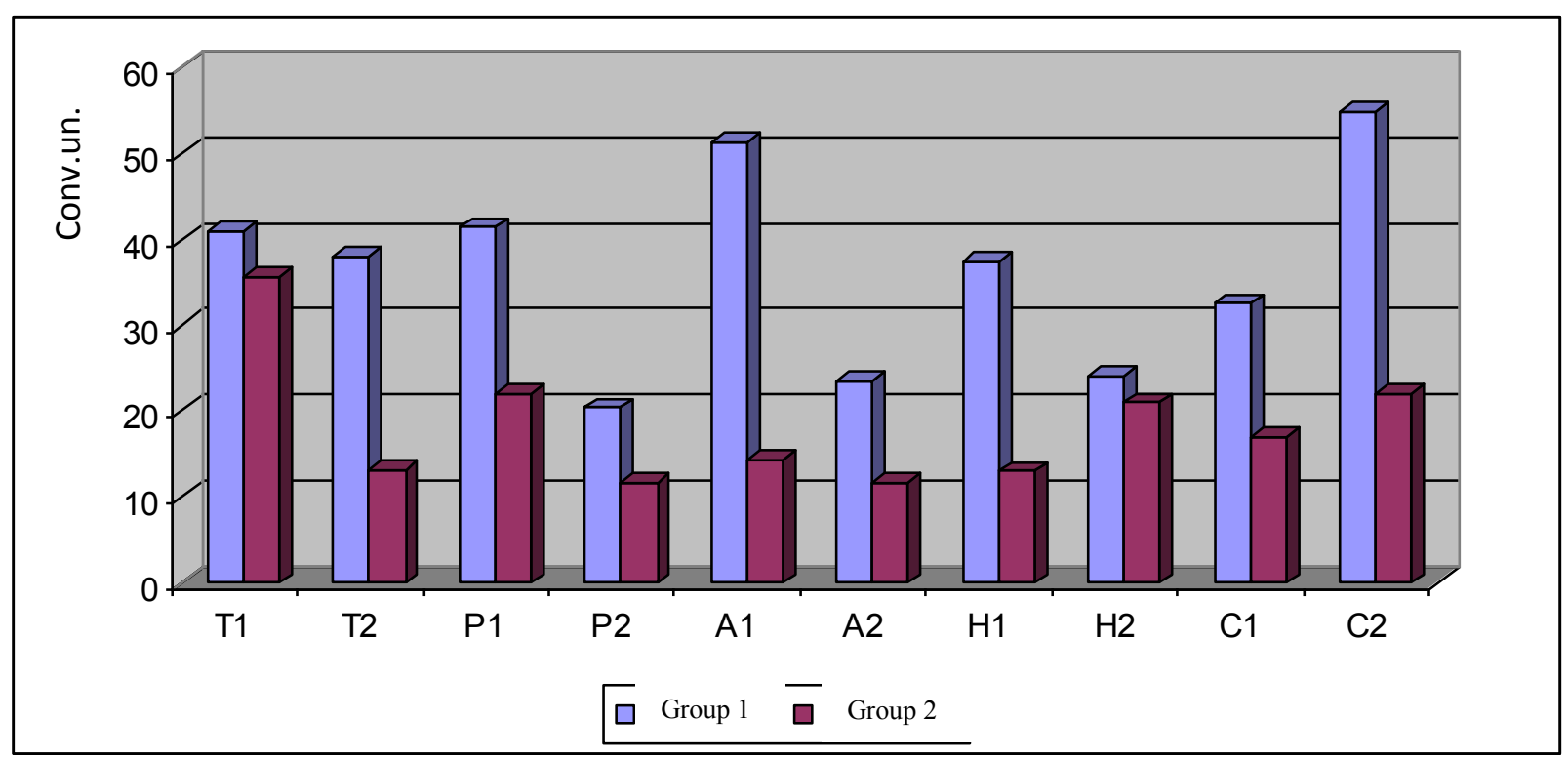

Fig. 1. Dynamic of system's formation indicators of arm-wrestlers

Notes: $\mathrm{T}$ - anxiety, $\mathrm{P}$ - workability, A - activity $\mathrm{H}$ - state of mood, $\mathrm{C}$ - self-feeling, 1 - before competitions, 2 - after competitions.

First of all the following fact attracts attention: contribution of all components of sportsmen-beginners is significantly lower than of experienced sportsmen. It shall be assessed as one more proof of worse psychological fitness of $2^{\text {nd }}$ group sportsmen.

It was found that the highest contribution to system of experienced sportsmen before competition is activity, i.e. psychological orientation on victory in future duels. Workability and anxiety are characterized by less, but rather significant values. It proves one more the made earlier assumptions about their importance for sportsmen's successfulness. Initial state of mood and self-feeling are lower and it can be interpreted as result of expectation stress. Dynamic of indicators confirms made earlier assumptions: reduction of workability, activity and state of mood reflect formation of 
fatigue. Practically stable anxiety illustrates post-stress state. Increase of self feeling is an indirect proof of successfulness of $1^{\text {st }}$ group sportsmen.

In $2^{\text {nd }}$ group we observed rather low contribution in initial state of all components except anxiety. Its increase undoubtedly proves formation of expectation stress. After competitions we registered reduction of contribution of anxiety and workability, insufficient reduction of activity and little increase of contribution of mood and self-feeling. These changes can be explained by peculiarities of sportsmen-beginners' state. Reduction of contribution of anxiety says about finishing of expectation stress. Workability and activity illustrate formation of fatigue. Mood and self-feeling shows optimizing of psycho-emotional status of sportsmen-beginners, which is connected with finishing of competition loads and certain "happiness", connected with it. Analysis of dynamic of psychological status indicators' contribution into sportsmen's condition proves made earlier assumption about changes in sportsmen's organisms under influence of competition loads. It permits to regard experienced sportsmen's condition as more resistant to competition stress.

\section{Discussion}

Changes in sportsman's psychological status appear in time and as a result of his professional functioning (trainings, competitions). It gives foundations for their studying and analysis. In our contest competitions shall be interpreted as extreme situations. Such situations put forward special requirements to sportsmen. They influence of psychological status, dynamic of which can be regarded as reflection of formation of adaptation. Analysis of available works, devoted to this problem, witnesses about similarity of literature data and results, received by us. Ermolaeva Y.S. thinks that levels of dancers' personal and situational anxiety is one of criteria of competition functioning's effectiveness [16]. High level of anxiety requires formation of self confidence and belief in success. Low level requires increase of activity, exiting of interest, responsibility in solution of training tasks.

On assessing of psychological status of chess players A.V. Khoroshavina, I.L. Udovenko, Ye.A. Strikalenko, O.G. Shalar conclude that chess players with high level of will self-regulation are characterized by calmness, self confidence, emotional stability, reliable self-control in different situations [10]. It is evident that these features of junior chess players influence positively on their competition results.

The data of Ivaskiene V.P., Skyriene V.V., Markevičius V.Z. witness that self-feeling, activity and state of mood of girl students in Judo and sambo in competition day permit them to achieve high results [20]. In its turn situational anxiety of most of these sportswomen is rather low. Researches of students, participating in Greco-Roman wrestling and boxing [18], Judo and sambo [19] resulted in the fact that self-feeling, activity and state of mood of sportsmen at eve of competitions was on high level. Situational anxiety was low.

V.A. Romanenko, N.V. Krayniaya, V.A. Mosenz, V.M. Prikhodko cinducted correlation analysis between parameters of anthropometric status and indicator of anxiety. They concluded that most of connections are characteristic for anxious girl students, comparing with not anxious ones [8]. In the first anthropometric and strength characteristics are interconnected $(0.31<\mathrm{r}<0.83)$ with anxiety positively. With indices of physical conditions by Erisman and chest they connected negatively $(0.62<\mathrm{r}<0.64)$. The second group girl students had body mass, strength of back and Ketle's index having negative correlation with anxiety. The rest indicators are positively connected $(0.36<\mathrm{r}<0.53)$ with this psychological characteristic.

At the same time results, received by M.F. Khoroshukha [11] are to certain extent opposite to the obtained by us. He thinks that higher level of anxiety and low level of aggressiveness are intrinsic to sportsmen-representatives of kinds of sports, oriented on higher endurance. For sportsmen of speed-power kinds of sports high aggressiveness is characteristic, to which lower indicators of anxiety correspond.

Thus, the received results deepen available information about peculiarities of psychological status of martial arts' sportsmen, its dynamic in process of competitions. The applied methodic of processing and analysis of data permit to more specifically differentiate condition of sportsmen of different qualification.

\section{Conclusions:}

The conducted researches permitted to determine certain changes in psychological status of different qualification AW sportsmen under influence of competition loads. Optimal condition of separate components of experienced sportsmen was confirmed as well as their favorable dynamic under competition loads. All these illustrate high level of functioning's reliability. The received results permit to regard specificities of psychological status as important factors, determining progress of sportsmanship. They give foundation for including of methodic, oriented on rising of stress resistance, into 
complex of AW sportsmen's training. The applied methods permit to promptly and adequately assess sportsmen's condition, prognosticate their successfulness and can be used in monitoring.

\section{Acknowledgement}

The research has been fulfilled in the frames of SRW "Theoretical and applied principles of construction of physical development, physical fitness and physical condition's monitoring in different strata of population"».

\section{Conflict of interests}

The authors declare that there is no conflict of interests.

\section{References:}

1 Antomonov MIu. Matematicheskaia obrabotka i analiz mediko-biologicheskikh dannykh [Mathematical processing and analysis of medical-biological data], Kiev; 2006. (in Russian)

2 Viatkin BA. Upravlenie psikhicheskim stressom v sportivnykh sorevnovaniiakh [Control of psychic stress in sport competitions], Moscow: Physical Culture and Sport; 1981. (in Russian)

3 Krivonosov MV, Podrigalo LV, Miteleva TIu. Profilaktika donozologicheskikh rasstrojstv zreniia u shkol'nikov [Prophylaxis of pre-nosological disorders of schoolchildren's eyesight]. Gigiienichna nauka ta praktika na rubezhi stolit' 2004;2:200-201. (in Russian)

4 Muntian VS. Optimizaciia rezul'tativnosti sorevnovatel'noj deiatel'nosti sportsmenov na osnove povysheniia urovnia ikh psikhologicheskoj ustojchivosti [Optimization of efficiency of sportsmen's competition functioning on the base of increase of their psychological stability]. Physical education of students 2010;3:55-58. (in Russian)

5 Podrigalo LV, Danilenko GN. Donozologicheskie sostoianiia u detej, podrostkov i molodezhi: diagnostika, prognoz i gigienicheskaia korrekciia [Pre-nosological states of children, adolescents and youth: diagnostic, prognosis and hygienic correction], Kiev: Genesis; 2014. (in Russian)

6 Podrigalo LV, Galashko MN, Galashko NI. Study and evaluation of indicators of relationships motor analyzer sportsmen of armsport. Physical Education of Students 2013;3:46-49. doi:10.6084/m9.figshare.669671

7 Podrigalo LV, Istomin AG, Galashko NI. Monitoring funkcional'nogo sostoianiia sportsmenov $v$ armsporte: mediko-gigienicheskie i sportivno-pedagogicheskie aspekty [Monitoring of sportsmen's functional state in armwrestling: medical-hygienic and sport-pedagogic aspects], Kharkov: XNMU Publ.; 2010. (in Russian)

8 Romanenko VA, Krajniaia NV, Mosenz VA, Prikhod'ko VM. Lichnostnaia trevozhnost' - determinanta antropofunkcional'nogo statusa studentok [Personal anxiety as determinant of anthropological-functional status of girl students]. Pedagogics, psychology, medical-biological problems of physical training and sports 2011;11:95-98 (in Russian)

9 Sinajko VM, Gavenko VL, Sokolova IM. Sposib ocinki trivogi, robotospromozhnosti, aktivnosti, nastroiu ta samopochuttia [Mean of assessment of anxiety, workability, activity and self-feeling]. Patent 197(1). 2002. (in Russian)

10 Khoroshavina AV, Udovenko IL, Strikalenko EA, Shalar OG. Uverennost' v sebe, kak zalog uspeshnoj sorevnovatel'noj deiatel'nosti iunykh shakhmatistov [Self confidence as the pledge of junior chess players' successful competition functioning]. Physical education of students 2012;4:125-129. (in Russian)

11 Khoroshukha MF. Vivchennia vzaiemozv'iazku mizh agresivnistiu i trivozhnistiu u iunikh sportsmeniv 13-16 rokiv $\mathrm{z}$ riznoiu spriamovanistiu trenuval'nogo procesu [Study of interconnection between aggressiveness and anxiety of junior, 13-16 years' old, sportsm,en with different orientation of training process]. Pedagogics, psychology, medicalbiological problems of physical training and sports 2011;4:154-156. (in Russian)

12 Shumakova NIu. Vzaimosviaz' fizicheskikh uprazhnenij s agressivnym povedeniem podrostkov [Interconnection of physical exercises with aggressive behavior of adolescents]. Teoriia i praktika fizicheskoj kul'tury 2002;9:53-56. (in Russian)

13 Asci FH. The effects of physical fitness training on trait anxiety and physical self-concept of female university students. Psychology of Sport and Exercise 2003;4:255-264. http://dx.doi.org/10.1016/S1469-0292(02)00009-2

14 Byrne AE, Byrne DG. The effect of exercise on depression, anxiety and other mood states. Journal of Psychosomatic Research 1993;37:565-574. http://dx.doi.org/10.1016/0022-3999(93)90050-P

15 Cocks M, Moulton C-A, Luu S, Cil T. What Surgeons can Learn From Athletes: Mental Practice in Sports and Surgery. Journal of Surgical Education. 2014;71(2):262-9. 
Ermolaeva YS. Level of anxiety as one of the criteria of efficiency of emotional stability in sport dancing. Pedagogics, psychology, medical-biological problems of physical training and sports 2015;2:22-25. http://dx.doi.org/10.15561/18189172.2015.0204

17 Gorczynski P. Sport and Physical Activity for Mental Health. Mental Health and Physical Activity. 2010;3(2):1023.

18 Ivaskiene V, Liaugminas A, Liaugminas S. Emotions in grecoroman wresters and boxers before the competition. Education. Physical Training. Sport 2010;3(78):29-33.

19 Ivaskiene V, Raskevicius K, Cepelioniene J, Markevicius V. Emotions in sambo and judo athletes students before the competition. Physical Culture and Sport in Universities. Kaunas: Technologija; 2012.

20 Ivaskiene VP, Skyriene VV, Markevičius VZ. Comparative analysis of prestart condition of students girls in Olympic and non-Olympic kinds of sport. Physical education of students 2013;4:27-30. http://dx.doi.org/10.6084/m9.figshare.669683

21 Jewett R, Sabiston CM, Brunet J, O’Loughlin EK, Scarapicchia T, O’Loughlin J. School Sport Participation During Adolescence and Mental Health in Early Adulthood. Journal of Adolescent Health. 2014;55(5):640-4.

22 Lueshen G. Checting in sport. Social Problem in Atletics: Essays in the Sociology of sport. Urbana Chicago-London: Univ. Illinois Press; 1976.

23 Massey WV, Meyer BB, Naylor AH. Toward a grounded theory of self-regulation in mixed martial arts. Psychology of Sport and Exercise. 2013;14(1):12-20.

24 McMahon JA, Penney D. (Self-) surveillance and (self-) regulation: living by fat numbers within and beyond a sporting culture. Qualitative Research in Sport, Exercise and Health. 2012;5(2):157-78.

25 Nezhad MAS, Besharat MA. Relations of resilience and hardiness with sport achievement and mental health in a sample of athletes. Procedia - Social and Behavioral Sciences. 2010;5(0):757-63.

26 Peckham AD, McHugh RK, Otto MW. A meta-analysis of the magnitude of biased attention in depression. Depression and Anxiety 2010;27(12):1135-1142. http://dx.doi.org/10.1002/da.20755

27 Perron A, Brendgen M, Vitaro F, Côté SM, Tremblay RE, Boivin M. Moderating effects of team sports participation on the link between peer victimization and mental health problems. Mental Health and Physical Activity. 2012;5(2):107-15.

28 Rogers RG. Mental Practice and Acquisition of Motor Skills: Examples from Sports Training and Surgical Education. Obstetrics and Gynecology Clinics of North America. 2006;33(2):297-304.

29 Rutter LA, Brown TA. Reliability and validity of the dimensional features of generalized anxiety disorder. Journal of anxiety disorders 2015;29:1-6. http://dx.doi.org/10.1016/j.janxdis.2014.10.003

30 Scoffier S, Gernigon C, d' Arripe-Longueville F. Effects of achievement goals on self-regulation of eating attitudes among elite female athletes: An experimental study. Psychology of Sport and Exercise. 2012;13(2):201-7.

31 Scoffier S, Paquet Y, d' Arripe-Longueville F. Effect of locus of control on disordered eating in athletes: The mediational role of self-regulation of eating attitudes. Eating Behaviors. 2010;11(3):164-9.

32 Snyder E, Spreitzer E. Social Aspects of sport. Englewood Cliffs (N.Y.): Prentice Hall; 1978.

33 Tamminen KA, Crocker PRE. "I control my own emotions for the sake of the team": Emotional self-regulation and interpersonal emotion regulation among female high-performance curlers. Psychology of Sport and Exercise. 2013;14(5):737-47.

34 Xiong J. The Functions and Methods of Mental Training on Competitive Sports. Physics Procedia. 2012;33(0):2011-4. 


\section{Information about the authors:}

Podrigalo L.V.: $\quad$ http://orcid.org/0000-0002-7893-524X; I.podrigalo@mail.ru; Kharkov State Academy of Physical Culture; Klochkovskaya str. 99, Kharkov, 61022, Ukraine.

Galashko M.N.: http://orcid.org/0000-0001-5278-9806; infiz@kharkov.ukrtel.net; Kharkov State Academy of Physical Culture; Klochkovskaya str. 99, Kharkov, 61022, Ukraine.

Galashko N.I.: $\quad$ http://orcid.org/0000-0002-7708-9504; infiz@kharkov.ukrtel.net; Kharkov State Academy of Physical Culture; Klochkovskaya str. 99, Kharkov, 61022, Ukraine.

Cite this article as: Podrigalo L. V., Galashko M. N., Galashko N. I. Study of specificities of arm wrestlers' psychological status in competition period.. Physical education of students 2015;3:44-51. http://dx.doi.org/10.15561/20755279.2015.0306

The electronic version of this article is the complete one and can be found online at: http://www.sportpedu.org.ua/html/arhive-e.html

This is an Open Access article distributed under the terms of the Creative Commons Attribution License, which permits unrestricted use, distribution, and reproduction in any medium, provided the original work is properly cited (http://creativecommons.org/licenses/by/3.0/deed.en).

Received: 16.06 .2015

Accepted: 29.06.2015; Published: 30.06.2015 